\title{
Agouti and Babassu
}

\section{Nigel Smith}

Both agoutis and the babassu palm thrive in secondary growth where primary rain forest has been removed, as is happening widely in South America, notably in Brazil. The agouti is also a prolific and easily farmed animal that provides good meat. The author suggests that farming of this native mammal would be much more likely than beef to succeed among the settlers coming in along Brazil's newly bulldozed roads.

Most major Amazonian game species, such as tapir Tapirus terrestris, peccary Tayassu sp. and red brocket deer Mazama americana disappear rapidly, or are at least reduced, when their primary rain forest habitat is destroyed. In Amazonia secondary growth areas are depauperate of large game animals such as the 80-kilo whitetailed deer Odocoileus virginianus, in striking contrast to disturbed habitats in central and northern South America. However, the rodent agouti Dasyprocta aguti, one of the favoured game species, appears actually to increase in secondary growth and pasture. This is due to the ubiquitous babassu palm Orbygnia speciosa, for the cotia, as the agouti is known in Brazil, greatly appreciate the pulpy mesocarp of its fist-sized fruits.

In primary forest babassu is sparsely dispersed, but when man invades, with slash and burn agriculture, this 20 -metre-high fireresistant palm proliferates explosively. Fire liberates the 1-4 oily nuts in the extremely hard endocarp, and these germinate readily in the nutrient-rich ash. (Without fire the endocarp takes several years to rot before the nuts are free to send off tap roots.) After germination, the nascent photosynthetic shoot grows downward into the soil before breaking through the surface; this is a protective measure against fire. The hardened endocarp also protects the nuts from predators whereas the mesocarp serves to entice potential dispersal agents, such as the agouti.

The purpose of this note is to suggest the possibility of farming cotia in the under-exploited babassu forests that occupy abandoned fields and degraded pastures, especially in Brazil's south-eastern Pará state, where soils have been eroded and leached of their valuable nutrients and are no longer suitable for agriculture. For cotias the babassu provides food, shade and shelter: bunches of several hundred fruit each are produced continually, and thousands must fall to the ground from a mature tree in the course of a year; the massive fronds provide ample shade, while fallen and rotten logs offer a secure retreat at night from predators such as ocelot Felis pardalis, margay Felis wiedii and jaguarundi Felis jaguarundi.

Instead of clearing vast areas of rain forest for cattle pasture, as is being done along pioneer highways such as the Transamazon, some attention might be paid to the possibilities of farming and domesticating native animals. Few of the settlers flooding the interior in 
the wake of the recently bulldozed roads can afford, let alone raise, beef. But small-scale agouti farming with babassu offers the peasant a promising and inexpensive alternative. Although not as prolific as rabbits, an adult agouti weighs three kilos and the female can produce up to three litters a year averaging two offspring each. Large commercial undertakings in urban centres could profit from the ready market for cotia meat. Restaurants in Belém, for example, used to offer a variety of cotia dishes at prices equivalent to choice filet mignon. Commercial exploitation of wildlife is now outlawed in Brazil, and game farming offers the only legal alternative source of regional delicacies.

\section{Who Cares in Hawaii?}

\section{Jerome J. Pratt}

More than 95 per cent of Hawaii's original fauna and flora occurs nowhere else in the world. In 1965 the compiler of the Birds Red Data Book, Jack Vincent, listed 25 of Hawaii's original 69 bird species as extinct. With the discovery of a new not yet named Honeycreeper (Drepanidiae) on Maui in 1973, by a National Science Foundation sponsored expedition and the re-discovery of the Maui nukupuu Hemignathus lucidus effinus in 1967, the count changed to 70 known species with 24 extinct. Of Hawaii's remaining 46 endemic birds 27 are threatened with extinction.

At the moment the extermination of several endangered birds is being accelerated by official indifference. If it had not been for $\mathbf{M r}$ Herbert Shipman of Hilo, Hawaii, the Hawaiian goose or nene Branta sandvicensis could have become extinct because of this attitude. In 1935, the entire flock of 42 nene in the hands of the Territorial Board of Agriculture and Forestry were given to various sugar and pineapple plantation managers and territorial senators, and by 1950 only one of those 42 was known to be alive-the gander of a pair given to the Honolulu Zoo. However, Mr Shipman had maintained a few semi-wild nene on his ranch for many years: in 1949 his flock numbered eleven birds and it is from these eleven that, with time and talent furnished by aviculturists in the United States and in England (the Wildfowl Trust) the species has been perpetuated, and captive-reared birds have been returned to Hawaii and successfully established in the wild.

The Hawaiian stilt Himantopus himantopus knudseni has not been as lucky as the nene, and this beautiful bird is in extreme danger. Its habitat is being destroyed to expand facilities for tourism. The bird's most important habitat is Kanaha Pond, on the island of Maui, which, together with adjacent lands, is state-owned property under the jurisdiction of the Department of Transportation as part of the Kahului Airport. This area is not needed for airport enlargement and could become a permanent wildlife sanctuary.

To the dismay of conservationists, Kanaha Pond has been chosen 